\title{
Changes of Religious Behaviours: Sociological Analysis of Literature of The Novel Al-Thaliyâniy by Syukrî Al-Mabkhũt
}

\author{
Abdul Fadhil \\ State University of Jakarta \\ abdul_fadhil21@yahoo.co.id \\ Sangidu \\ Gadjah Mada University Yogyakarta \\ sangidu@ugm.ac.íd \\ Fadlil M. Manshur \\ Gadjah Mada University Yogyakarta \\ fadlildsugm@gmail.com
}

\begin{abstract}
Novel al-Thaliyâniy by Shukrî al-Mabkhût is a novel that tells the journey of social and political history of the nation of Tunisia's democracy. The novel represents the behaviour of the people and the leaders of Tunisia who changed their religious behavior.

Changes in religious behavior of the Tunisian society are categorizedinto three groups. The first group is related to normative religious teachings, such as not practicing religious duties, not praying for thedeceased parents, lacking integrity of Islam (murû'ah), and lacking the religious knowledge. The second group is a behavioral change in attitude and personality. Acts that fall under this category are for example getting drunk and having sloppy style; gossiping and meddling in the affairs of others; lazy and talkative; lacking the authoritativeness and firmness; extravagance and wasteful; being hypocrites (hypocrites); and lastlyact of lying and slander. The third group behavioral changes is related to family values, such as educating children with hard and rough approaches; being against the parents; seclusion, committing adultery and promiscuity; and sexual abuse of children.

This is the conclusion of this dissertation research, and lastly, the ath-Thaliyâniy novel is a mirror of the Tunisian people and it is hoped that it can be a learning experience.
\end{abstract}

Keywords: Thaliyâniy, Tunisian Society, Religious Behavior

\section{A. Introduction}

There have been changes in the Islamic world since the first half of the 19th century as a result of imperialism. Changes were originated from Egypt through a series of efforts made by Muchammad 'Ali and his successors. From there also the various new ideas emerge carried along by the culture and experience of Western modernity, such as rationalism, nationalism, democracy, and secularism which later gave birth to various new issues. As it is known, the efforts of Muchammad 'Ali was motivated by a consciousness of backwardness of the Islamic world from the advancement of the West, after the occupation of Egypt in 1789 by Napoleon Bonaparte and the first residents of this city witnessed the 
new types of military power and competitors from European countries. ${ }^{1}$ Since then, largescale changes in the social, political, cultural, and religious aspects which originally occurred in Egypt spread to almost all of the Islamic world. The changes then became known as the beginning of the process of modernization.

The changes brought about by modernization, unavoidably, also spread into the area of religion. This is because, in addition, the West which is a measure of modernity, has done a secularization which leads to marginalization and reduction of the role of religion in world affairs.Changes and developments are also the nature and demand of science. ${ }^{2}$

Works of literature in the form of novel were born as a response to modernity. In the struggle between the "old world" and "new world" offered by modernity, writers, through the works of creative, offer "the possible world" ${ }^{3}$, where some values in the old and new worldscan be negotiated and reconciled. As the works of other scientists, the creative works of writers basically can also be the authoritative source for understanding the thought and society.

The nuance of changes in various aspects of community life, especially in the Middle East, seems more fitting in al-Thaliyâniy ${ }^{4}$ novel written by a citizen of Tunisia,Shukri alMabkhût. This study was conducted to see and understand how the reality changes and its impact on social, political, economic, and religious aspects of Tunisian community. This is achieved through analysing the al-Thaliyâniynovel by al-Mabkhûtwith sociological analysis approachof literature.

\section{B. Changes in Religious Behavior}

Changes means turning into something else, or transition (transition) of the form of existence to another form of existence. Behavior means individual responses or reactions to stimuli or environmental. ${ }^{5}$ While religiosity derived from the basic religious meaning system, the principle of belief in God with the teachings of worship and obligations relating to trust it. Religious said it has received the prefix "to" and the suffix "an" which

${ }^{1}$ Harun Nasution, Pembaharuandalam Islam, SejarahPemikirandanGerakan, (Jakarta: BulanBintang, 1999), p. 11

${ }^{2}$ HarunNasutiondanAzyumardiAzra (Ed.),Perkembangan Modern dalam Islam.(Jakarta: YayasanObor Indonesia, 1985), p. 1

${ }^{3}$ UmbertoEco,.The Limits of Interpretation,(Bloomington-Indianapolis: Indiana University Press, 1994), p. 69

${ }^{4}$ Syukrî al-Mabkhût, al-Thaliyâniy,(Tûnis: Dâr al-Tanwîr li al-Thibâah wa al-Nasyr, 2014)

${ }^{5}$ DepartemenPendidikandanKebudayaan,KamusBesarBahasa Indonesia,(Jakarta: BalaiPustaka, 1995), p. 755 
has the meaning of something (any action) associated with religion. ${ }^{6}$ So religious behaviors are activities or behaviors that are based on religious values. Religious behavior raises awareness of religion and religious experience. ${ }^{7}$

Changes in religious practice more widely discussed with the approach of psychology. Modern psychology seems to give a special portion for religious behavior, although the psychological pendekata used to the role of religion in the lives of the human psyche. The most extreme opinion about it shows how religion has been assessed as part of life is limited to empirical experience. Psychology of religion that is used is one proof of the existence of particular concern to psychologists.

According to Skinner (via Ancok) ${ }^{8}$, religious activities become reinforcing factors as behavior relieve tension. Social institutions, including religious institutions, in charge of keeping and maintaining the behavior or habits of the people. Humans respond to the demands contained in the institution and help preserve the past by following the rules that have been standard. This is in line with the principles of behaviorism theory that sees human behavior was born because of the stimulant (stimuli from outside himself). Humans behave religion because it is driven by the stimulus of punishment and reward (reward). Humans just a robot that moves mechanically by punishment and reward. ${ }^{9}$

Religious behaviors grow and develop in line with the development of man from birth to adult and are influenced by the environment. The more a religious experience to someone from his youth will be the more attitudes, actions, behavior and how to deal with life according to the teachings of his religion. Personality parents, attitudes and ways of life are elements of education that indirectly that by itself will go into private children who grow them.

\section{Sociology of Literature}

This research is based on the theory of sociology of literature with theoretical approach formulated by Swingewood. Swingewood ${ }^{10}$ defines sociology as a scientific and objective study of man in society, the study of institutions and social processes. The statement is a social relationship, linked to each-other, among individuals receiving social

\footnotetext{
${ }^{6}$ DepartemenPendidikandanKebudayaan,KamusBesarBahasa Indonesia,(Jakarta: BalaiPustaka, 1995), p. 755p. 11

${ }^{7}$ JalaluddinRakhmat,Psikologi Agama, (Bandung: PustakaMizan, 2003), p. 32

${ }^{8}$ DjamaludinAncok, Psikologi Islam,(Yogyakarta: PustakaPelajar, 2011), p.73

${ }^{9}$ DjamaludinAncok, Psikologi Islam,(Yogyakarta: PustakaPelajar, 2011), p. 74

${ }^{10}$ AlanSwingewood, "Theory" in Diana Laurenson\& Alan Swingewood, The Sociology of Literature, (London:Paladin, 1972), p.11
} 
institutions that are considered necessary and correct. Sociology itself not just discuss about the sustainability of the community structure and social interaction, but also sociology also discusses the symptoms of social change in society, both individually and revolutionary.

Swingewood is a sociologist of post-Marx and Engels. Before its emergence, the two men had argued about human life on the base material. Capitalism controlled by financier is a scourge for the proletarian and workers. Thus, the power or the strength of the group of investors from among the feudal destroyed by the workers. It is then also affect the appearance of literary works that smelled propaganda for resistance against feudalism.

In connection with his theory, Swingewood provide three concepts in conducting sociological research literature, namely; literature as a mirror of social, literary views of the production process and authorship, and literature in relation to history.

\section{1) Literature as Social Mirror}

A literary work, not only presents a beautiful language like what was said the Russian formalists. However, literature is a documentation of the history, literature as well as social reflection. To view a particular phenomenon, literary documentation can be a place to open and view the results of a behavior in a given society. Likewise with Swingewood who said that literature is a mirror. The mirror is a reflection of self, as well as analogous to a literary work is a reflection of a reflection of society. ${ }^{11}$

Swingewood also confirmed that the occurrence of a social change has an influence on a work as a reflection of social, for a variety of entry of mass culture. This would add to the treasures of literature as social reflection.

\section{2) Authorship and Production}

Approaches of authorship and production is an important part for the reviewer sociology of literature. Swingewood mention that this approach was moved from discussion to discussion of literary production of literary works, especially the situation of the author. After entering the industrial era, the phenomenon of the market which facilitate the authors get royalties then weaken literature as a work that holds a lot of value in it. This is what causes a work faded into the market due to its role. An author creates a work no longer fit with that as authorship, but it becomes a market order because of the large demand for a particular work.

\footnotetext{
${ }^{11}$ AlanSwingewood, "Theory" in Diana Laurenson\& Alan Swingewood, The Sociology of Literature, (London:Paladin, 1972), p. 13
} 
Another case with the great literary work is a science that puts the community is outside of him, causing the literary works can make a major contribution to society, ie, as the resulting product of society and provide benefits for a group of people who produced it. This relationship between literature and society give symbiosis with each other.

3) History and Literature

Historical and literary works are like two sides of a coin that can not be separated. The continuity of the history that happened in the past is recorded in a literary work. Literature has its place as the author of a media channel-keresahannya unrest in the past in the form of literature.

As a social documentation, literature can be a historical archive. The social structure in a literary is able to explain the phenomenon of social reality as documentation. As a work-free, there is no doubt that the literary work also deny the spirit of the time. For example, a literary work is present but historically different from the existing historical facts. This could happen in a work, because there is interference authors give an aesthetic value in a work. It could also happen in the facts of history, there is a specific power authority for not presenting the facts, but literature can express it through a story.

The three concepts of sociology of literature for researchers can map the genetic phenomenon of society in linearity, while finding alignments such a work. These three concepts are then used in conjunction with the object of the same material, it is to see whether a literary work reflects the social conditions of a society or has been influenced by the interests of the production process. In that sense, a pure act reflects a social situation or perhaps a work become a way of interest on the ruler and just as mass production only.

The concept of religious behavior changes as described above into a formal object in this study by examining the texts in al-Thaliyâniy novel, as a material object, and then analyzed with analytics approaches sociology of literature. From then expected to form a relationship between the text of the novel to the social reality in the context of changes in religious behavior.

\section{Structure of Text in Novel}

There are several forms of religious behavior changes that can be expressed from the novel Ath-Thaliyâniy. The forms of these behavioral changes can be divided into three groups: first, changes in religious behavioror normative aspect; second, changing attitudes (moral) or religiousity; and third, changes to family values. Disclosure of such religious behavior change also is juxtaposed (homology) with the text in the novel. 


\section{Changes in Religious Behavior Normative}

Religious norms are the rules that bind every religious believer to carry it out. Religious norms in the form of religious instruction should be done (obligatory), restrictions that must be shunned (legal harâm), the choice between may work or not (permissible) things that are recommended to be implemented (mandûb or sunnah) and things that should be left (makrûh).

Religious norms also have consequences for the perpetrator to do it. For people who perform acts that payers will get the reward and do not be regarded as sinful. Conversely, for those who do charâm deeds, he will get a sin and in certain cases he was penalized, while those who leave will be rewarded. For people who do deeds mandubsunnah or she will be rewarded, and that does not work is not a problem. Instead, the act makruh people who do not act precisely why and stay away from getting the reward. While such actions are permissible should be done or not.

Changes in behavior associated with religious norms mentioned in the novel is not running a religious duty ${ }^{12}$, do not pray for his dead parents ${ }^{13}$, lack of integrity of Islam (murû $\left.{ }^{\mathrm{ah}}\right)^{14}$, and a lack of insight into the religious sciences ${ }^{15}$.

\section{Changes in Attitudes Toward Personality}

Attitude is a state in man that drives to act or do in social activities with certain feelings in response to a situation or condition objects in the surrounding environment. In addition stance also gives the readiness to respond to positive or negative nature of the object or situation.

In social interaction, individuals form a specific pattern of attitudes toward various psychological object faces. This is why the attitude can change. Among the various factors that influence the formation of attitudes among them is a personal experience, culture, others that are considered important, mass media, educational and religious institutions, or other emotions. Personal experience will be easier to shape attitudes if it involves emotional factors. In situations that involve emotion, appreciation will experience will be more profound and longer trace.

\footnotetext{
${ }^{12}$ Syukrî al-Mabkhût, al-Thaliyâniy,(Tûnis: Dâr al-Tanwîr li al-Thibâah wa al-Nasyr, 2014) p. 6

${ }^{13}$ Syukrî al-Mabkhût, al-Thaliyâniy,(Tûnis: Dâr al-Tanwîr li al-Thibâah wa al-Nasyr, 2014).p

${ }^{14}$ Syukrî al-Mabkhût, al-Thaliyâniy,(Tûnis: Dâr al-Tanwîr li al-Thibâah wa al-Nasyr, 2014)51

${ }^{15}$ Syukrî al-Mabkhût, al-Thaliyâniy,(Tûnis: Dâr al-Tanwîr li al-Thibâah wa al-Nasyr, 2014) p. 5758
} 
Acts that fall under this category of them got drunk and sloppy style ${ }^{16}$; gossip and meddle in the affairs of others ${ }^{17}$; lazy and talkative ${ }^{18}$; lacked the authority and firmness ${ }^{19}$; extravagance and wasteful ${ }^{20}$; behave hypocrites (hypocrites) ${ }^{21}$; and last lie and slander ${ }^{22}$.

\section{Changes To The Family Values}

Value is a precious good by the standards of logic (true or false), aesthetics (good or bad), ethics (proper or improper), and law (authorized or unauthorized). As well as a reference value and belief system or individual and social. Families are environments that there are some people ynag still have blood relations, and is the smallest unit of society consisting of the head of the family and some people gathered and stay somewhere under one roof in a state of mutual dependence. Is a system of family values, attitudes and beliefs consciously or not, to unite family members in one culture. Family value is also a guideline for the development of norms and regulations contained in the family environment.

The values in the family will go well if each member of the family to perform its role properly. Father as the husband of the wife and father of her children, a role as breadwinners, educator, protector and giver a sense of security, as the head of the family, as a member of a social group as well as members of social groups as well as members of the environmental community. Mother as a wife and mother of his children, to contribute to taking care of the household, as caregivers and educators of their children, protective and as one of a group of social role as well as community members from the environment, in addition, it is also the mother can act as breadwinners additional family. Children carry out the role of psychosocial accordance with the level of development of physical, mental, social, and spiritual.

The function of the family itself can be seen from several aspects. Viewed from the aspect of education, educating families and send their children to prepare for the maturity and the child's future. Families become an institution of socialization in preparing children to become good members of society. Aspects of protection, families protect children so that family members feel protected and feel safe. Aspects of the feeling, the family feeling and atmosphere instuitif children and other members in communicating and interacting among fellow members of the family, so that mutual understanding of each other in

${ }^{16}$ Syukrî al-Mabkhût, al-Thaliyâniy,(Tûnis: Dâr al-Tanwîr li al-Thibâah wa al-Nasyr, 2014), p. 9

${ }^{17}$ Syukrî al-Mabkhût, al-Thaliyâniy,(Tûnis: Dâr al-Tanwîr li al-Thibâah wa al-Nasyr, 2014, p. 23-24

${ }^{18}$ Syukrî al-Mabkhût, al-Thaliyâniy,(Tûnis: Dâr al-Tanwîr li al-Thibâah wa al-Nasyr, 2014)p. 27-30

${ }^{19}$ Syukrî al-Mabkhût, al-Thaliyâniy,(Tûnis: Dâr al-Tanwîr li al-Thibâah wa al-Nasyr, 2014)p. 34-35

${ }^{20}$ Syukrî al-Mabkhût, al-Thaliyâniy,(Tûnis: Dâr al-Tanwîr li al-Thibâah wa al-Nasyr, 2014), p. 330-

${ }^{21}$ Syukrî al-Mabkhût, al-Thaliyâniy,(Tûnis: Dâr al-Tanwîr li al-Thibâah wa al-Nasyr, 2014), p. 9

${ }^{22}$ Syukrî al-Mabkhût, al-Thaliyâniy,(Tûnis: Dâr al-Tanwîr li al-Thibâah wa al-Nasyr, 2014)., p. 21 
fostering harmony in the family. Religious aspect, family introduce and invite children and other family members through family head to instill confidence that regulate life and the life after the world. Economic, family earn money, regulate income in such a way so as to meet the needs of the family. Recreational aspects can be seen from how to create a fun atmosphere in the family, such as watching TV shows together, telling stories about each other's experiences, and more. Biological aspects, it can be seen from how families pass on the next-generation descendant. The most important of it all is to give love, attention, and a sense of security among families, and foster the maturation of the personality of the family members.

If the family members' roles and functions of the family is not running properly, there was a weakening and decline of the values of the family. The researchers' analysis of the novel al-Thaliyâniy suggests there are some changes in religious behavior associated with values in a family. The behavior change is like educating children with hard and rough $^{23}$; against the parents ${ }^{24}$; seclusion, commit adultery and promiscuity ${ }^{25}$; and sexual abuse of children ${ }^{26}$.

\section{E.Community Social Background}

\section{Social and Political History of Tunisia}

Republic of Tunisia (Arabic: الجمهرية التونسية) is an Arab Muslim country in North Africa, precisely in the Mediterranean coast. Tunisia is bordered by Algeria to the west and Libya to the south and east. Tunisians are mostly a mix of Arab and Berber descent. More than half the population of Tunisia living in big cities or small; the rest live mainly in farming villages. ${ }^{27}$

Tunisia's first dynasty was founded in 800 by the Aghlabid family. The prince from Tunisia to go far to conquer Sicily and Egypt. But this conquest expose Tunisia in attack rival principality. From the year 900 until the 1500s, Tunisia was ruled by a series of Muslim tribes -Fatimiyah, Almohade, and the Berbers, Hafsid. In the 1200s and 1300s, under the rule of the tribe Hafsid, Tunisia flourish again. In 1574, the region became a province of the Ottoman dynasty. For about 300 years, Tunisia has its own government, 58., p. 8

${ }^{23}$ Syukrî al-Mabkhût, al-Thaliyâniy,(Tûnis: Dâr al-Tanwîr li al-Thibâah wa al-Nasyr, 2014) p. 57-

${ }^{24}$ Syukrî al-Mabkhût, al-Thaliyâniy, (Tûnis: Dâr al-Tanwîr li al-Thibâah wa al-Nasyr, 2014), p. 34

${ }^{25}$ Syukrî al-Mabkhût, al-Thaliyâniy,(Tûnis: Dâr al-Tanwîr li al-Thibâah wa al-Nasyr, 2014)., p. 21

${ }^{26}$ Syukrî al-Mabkhût, al-Thaliyâniy,(Tûnis: Dâr al-Tanwîr li al-Thibâah wa al-Nasyr, 2014)., p. 3839; p. 108-109; p.318-319

${ }^{27}$ Ira M.Lapidus, History of Islamic Societies, (Cambridge: Cambridge University Press, 2002), p. $321-322$ 
although it remained part of the Ottoman dynasty. France, which already controlled the neighboring Tunisia, Algeria, Tunisia established a protectorate in 1883. After World War I (1914-1918), the Tunisian people started wanting greater self-government. But France rejected their demands.

During World War II (1939-1945), the battle in Tunisia interfere with the independence movement. In the early 1950s, after negotiations failed, Tunisia start a guerrilla war against the French. Achieved full independence in 1956. The Husseiniyah dynasty that had ruled since 1705 , ended in 1957 . Tunisia became a republic. ${ }^{28}$

Since becoming a republic until the revolution Yasmin in 2011, Tunisia was only led by two presidents, namely HabibBourguiba (1957-1987) and ZainalAbidin Ben Ali (19872011). Then after the revolution Yasmin which is the forerunner of the Arab Spring, Tunisia led by President MarzukiMunshif transition (2011-2014). Since 2014 until now headed by the president of Tunisia BejiCaidEssebsi after an election in $2013 .^{29}$

\section{Religious Thought in Tunisia}

Thought religion (Islam) in Tunisia is strongly influenced by the development of the political situation and social conditions as described above. Religious thought also related to government policies since independence is more inclined to the process of secularization Tunisia and marginalize the role of religion. As a result, the development of religious thought greater attention to Islamic religious movements.

According to al-Ghannûsyiy ${ }^{30}$, the phenomenon of Islam in Tunisia can be seen from different perspectives. This phenomenon from the point of the roots of thought underlying the formation of the phenomenon of Islam in Tunisia. Perhaps this approach will add a new alternative that helped the observer to interpret Islamic upheaval in Tunisia in response to the demands of time and space. Although there are assumptions about uniformity between various Islamic activities which have the same ultimate goal, namely revive Islam, society, and the law, but actually it was not the right assumption. The phenomenon of Islam in Tunisia is the fabric of a product of the struggle and the dynamics between the three elements of the Islamic movement. Three elements referred to is the style of traditional Islam, the Islamic Salafi (revivalists), and Islamic rational.

\footnotetext{
${ }^{28}$ Kenneth J.Perkins, A History of Modern Tunisia,(Cambridge: Cambridge University Press, 2004), p.110-134

${ }^{29}$ Abdesselem Mahmoud, "Social Movements in Tunisia and Egypt: A Tale of Two Revolutions" in International Journal of Social Science Studies, Vol. 3, No. 3; May 2015, p. 8-10

${ }^{30}$ Râsyidal-Ghannusyiy,Min Tajarrubât al-Harakat al-'Islâmiyyat fî̀ Tûnis,(Tûnis: Markaz alMaghârib li al-Buhûtsi wa al-Tarjamah, 2014), p. 7-10
} 
Traditional Islam in Tunisia is composed of three elements, namely: imitation in the field on the Maliki school of jurisprudence, theology and patterned Asy'ariyah Sufism. The elements are composed by Ibn 'Âsyir, a Maliki jurist, from referral sources Ash'ari theology, jurisprudence of Imam Malik, and the congregation Junaid al-Baghdadi.

Islamic revivalistik (salafi) built on the rejection of dogmatic theology and of the Islamic school and aims to restore all the problems at the source of Islam, the Koran and the Sunnah, the life-RasyidinKhulafa'ur, friends, and tabi'in. Another goal is to fight understand wasilah (intermediary) man's relationship with God and heresy-heresy in order to prioritize religious texts than the ratio. Method of thinking that promotes faith-moral dimension such that characterize the human being brothers and enemies. This method also deny the reality and culture nonislami even against schools of Islamic thought who else though. It is almost exclusively make up the system. ${ }^{31}$

Islamic rational began to emerge in the second half of the 1970s. In the first half of the 1970s, Islamic rational has been swept by a wave of al-Salafi Islamic Muslim Brotherhood. In the late 1970s and 1980s, the situation allows Islamic rationale for a comeback.

It is rational flow has not appeared in the first half of the 1970s, except when there is a variety of tension and dissatisfaction with the reality of the Islamic movement. Even Islamic groups more rationally defend themselves from the domination of the Brotherhood salafi groups. Political situation of the second half of 1970 to provide fresh air to this group to bring the ideas of reform through the magazine al-Ma'rifah. This magazine is supported by Western literature because of the weakness of religious materials in Tunisia in general after the closing of the University Zaituniyah. That fresh breeze that also play a role in generating a climate of rationalism, which in turn form a rational Islamic patterns.

Meetingthese schools of thought are not likely to occur in the Islamic community in Tunisia without going through a process of interaction and adaptat ion between them. Islamic patterns in Tunisia retains Maliki and Ash'ari theology at certain limits, and preserve religious traditions such as warning Mawlid the Prophet and Sufi poetry readings that have been ingrained in the community. However, the pattern of Islam in this country to deal with a wave of criticism of the Salaf group that seeks to eliminate these traditions and heresy as well as offering Islamic concepts of pure, comprehensive, and the foundations of the Islamic government.

\footnotetext{
${ }^{31}$ Charles E. Butterworth, Between the State and Islam, (Cambridge: Cambridge University Press, 2001), p. $27-28$
} 
The Islamic group rational retaining his thesis that the development of law in line with the reality without distinguishing between the teachings of a standard (tsabât) and developing (tathawwur). Even for this flow, which goes beyond the development of definitive texts can even be considered in order to realize Maqasid (the core purpose of a doctrine), for example the issue of polygamy.

\section{Gender Equality Movement and Feminism in Tunisia}

It may be said that Tunisia is a country very liberal in enforcing gender equality than other countries in the Middle East. At the beginning of its independence, Tunisia has set the laws on personal rights and the same family between men and women. But then the laws governing the rights of the individual have ups and downs in line with the interests of the government when dealing with people. In this case, there are three important aspects related to the relationship between state power, religious symbolism, and women's rights in Tunisia, namely (1) the purpose of the political state, (2) a state monopoly on women's rights and (3) the impact of natural of the country's progress. ${ }^{32}$

In the reign ruled by President HabibBourguiba (1957-1987) and Zine el-Abidine Ben Ali (1987-2011), the support of the Tunisian state for women's rights and religious freedom tends to go up and down as a result of shifting political purposes. From 1920 until independence, Tunisia nationalist leadership strives to maintain a united front against the French, who have sought to marginalize traditional headscarves and other religious activities.

At the beginning of his rule HabibBourguiba took a conservative approach to women-related issues. Stressing the importance of habits such as headscarves dimaknakan in words Bourguiba as "the last defense of national identity is in danger." Until Bourguiba encourage women to wear sefseri it, a white scarf traditionally described above hair and the whole body, as a means of consolidation cultural solidarity against the colonial power. However, in the next period in the 1960s and 1970s Bourguiba gradually change its policy strategy. in his capacity as president, he scoffs sefseri as a symbol of backwardness and women.

For the sake of political power interests, the Tunisian regime ignores the policies that have been established with extreme oppression, kleptocracy, and systematic violence against women from Islamic groups. The woman or her family members were suspected of

\footnotetext{
${ }^{32}$ Monica Marks, "Women's Rights before and after the Revolution"in The Making of the Tunisian Revolution: Contexts, Architects, Prospects, Nouri Gana (ed.), (Edinburgh: Edinburgh University Press, 2013), p. 224-251
} 
affiliation whatsoever in political parties is prohibited, especially against the party AlNahda and the Tunisian Communist Workers Party (POCT) 'Workers Party Communist Tunisia', will experience incommunicado detention, imprisonment, torture, and sometimes dilecehankan.

Then with regard to the second reason the state has a monopoly of women's rights, can be exemplified in the policy of HabibBourguiba during his regime that marks the good of the country that has given monopoly rights of women fully to regulate themselves, so that Tunisia was impressed termed "state feminism",

Bourguiba efforts to enforce and popularize the Personal Status Code in 1956 make an interesting case study in the regime of feminism. Indeed, executives monopoly that causes women's rights became one of the most important trends that emerged during the formation of the country Tunisia (1950 and 1960 years). Feminism in Tunisia is not a civil society movement that stands up to the 1990s, but it may be said through the law of personal rights (PSC) is regarded as a precious gift for the women in the midst of Middle Eastern societies are paternalistic and autocratic rule symbol of generosity.

And the third, which is the natural effect of the progress of the state. It can be seen from Bourguiba and Ben Ali's efforts to popularize the image of modern Tunisia by applying secular progressivism that supports women's rights. Bourguiba himself also thought to have contributed to contribute to the progress that has been achieved during his tenure. His followers had to make himself as the inspiring story with a bold program of secular modernization.

\section{Social Media, Fall of Ben Ali, and the Arab Spring}

Talking about social media in Tunisia can be assumed as well as the end of the rule of Ben Ali in Tunisia. Who would have thought a president long enough to power nearly 25 years should be lowered because of the role of social networking. Therefore, many observers argue that the revolution in Tunisia that led to the fall of Ben Ali from the presidency in fact it is a social media revolution.

Tunisia is one country that treats strict control over mass media and media information. Television and radio only owned by the government and if there is in fact also the owner of private television in government officials. News newspaper very strictly controlled and in case of suspected news is going against government policy directly banned. Tunisian society was nobody dared to oppose the government's policy.

Although the mass media at that time very strictly controlled government can not stem the flow of development of information and communication technology, especially 
the latest social media. ${ }^{33}$ Via laptops and mobile phones each person can communicate not only could speak and hear the sound of it, can even be seen straight people who are talking. Read newspapers and magazines do not need to go through printed, simply by clicking on newspapers and magazines. Mealui communication tool that every person has a "home" was in cyberspace. The house is no such thing as Facebook, Twitter, Instagram, WhatsApp, and so forth.

It should be recognized social media is not really a cause of action is the overthrow of Ben Ali's regime in February 2011. The cause was a sense of disappointment people, because of unemployment, poverty and corruption are widespread in Tunisia. Social networks on the Internet and mobile phones only accelerate and strengthen the resistance movement.

Like a virus, the popular revolution Tunisia quickly spread to other countries in the Arabian peninsula. The people's revolution in the Arab world - which later became known as the Arab Spring tersebut- subsequently spread to Libya, Yemen, Bahrain and Syria.

There are at least three important roles played by social media in contemporary social movements. First, social media - especially Facebook, Twitter and Youtube became the main communication media used in the new social movements. Second, social media become an alternative channel for distributing the issue when the traditional mass media - newspapers, magazines, radio, television - are silenced by the regime of the country. News Tunisian people's revolution that inspired the young people of Egypt, for example, many obtained through Facebook and Twitter instead of through newspapers or television. And third, proven social media use in mass mobilization. When and where the demonstration is done, who was involved, until the eyewitness report of streaming makes contemporary social movements to become more effective.

\section{F. Changes in Religious Behavior: The Relationship Between Structure Text and Reality Society}

\section{Ath-ThaliyâniyAs Novel Sociology of Literature}

Novel Ath-Thaliyâniy can be assumed to have met the criteria as the sociology of literature theory postulated by Swingewood. Based on the first criterion Swingewood theory, Novel Ath-Thaliyâniy a literary work that tells the life experience of the author's

\footnotetext{
33 NatanaJ. DeLong-Bas, "The New Social Media and the Arab Spring" http://www.oxfordislamicstudies.com/Public/focus/essay-0611_social_media.html.,accessed 5February 2017.
} 
friends since childhood until adulthood, even the author is also involved in that story. Social and cultural background of the authors at the time were described as such, which is one of the villages in the city of Tunis which society adherents Syadziliyyah congregation. Then the author tells how the villagers have finally changed when he was an adult. The changes in question concerns the changes in religious behavior.

Ath-Thaliyâniy novel also tells the community groups that exist in the village. Characterizations in the story, the Ath-Thaliyâniy itself, derived from the group highborn nobles Turkey. Told how her father as a finance ministry official in Tunisia. Her association with the mothers wife in Tunisia ordinary magnifying traveling abroad for shopping or recreation. Proximity characterizations stories with his friends from a poor family that causes it when students are more receptive to Marxist doctrine.

Differences communities in Tunisia is indeed not be equated as the difference with proletarian society Bourgeois society as happened in the western world, because the Tunisian society of adherents of Islam which teaches equality of humanity, so that the difference is not visible by naked eye. Nevertheless, in Tunisia's own doctrine of Marxist socialism is not prohibited by the state, the teaching may flourish and even set up a party.

In connection with his theory, Swingewood provide three concepts in conducting sociological research literature, namely; literature as a mirror of social, literary views of the production process and authorship, and literature in relation to the history. ${ }^{34}$

Referring to plot the novel, the author is not merely just share the experience of himself and his colleagues who become the main characterizations, of course, this novel as a social mirror to society, especially concerning changes in religious behavior Tunisian society. Tunisia $99 \%$ of the population are Muslims, but their life away from Islamic values. They've terbaratkan. They prefer and are proud to use the French language than their mother tongue, Arabic. Their lifestyle is not much different from the western lifestyle. Through this novel as if the author wanted to give a message should the Tunisian people back to their cultural roots, namely the Arab and Islamic culture.

Judging from the production process and authorship, this novel is a literary work sublime, because the winner of the prize prize literary works best Arabic IPAF (International Prize for Arabic Fiction (IPAF) in 2015 and a reader of literature from

${ }^{34}$ AlanSwingewood, "Theory" in Diana Laurenson\& Alan Swingewood, The Sociology of Literature, (London:Paladin, 1972), p 13 
around the world can get a way to download it via the internet. ${ }^{35}$ so, by looking at the interest of people to download the novel can be said that the novel as a paperback best seller. in terms of authorship, the novel a gain appreciation of the whole society, not only for the people of Tunisia, even from around the world. the appreciation is actually raised literary world, especially in the Middle East, from lethargy due to more people talk about politics than reading literary works.

In terms of historical and social documentary, this novel tells a historical record that occurred in the 1980s during the reign of president Bûrqaibah and illustrates how Tunisia distress and social unrest at the time. The historical documents are still relevant to look at the current condition.

\section{Occurrence Causes Behavioral Changes Religious}

Referring to the text of the novel and the plot changes that behavior is caused by several factors. First, secularization is systematically applied by the Tunisian government through policies that are oriented to the West, such as in the field of culture and education system. ${ }^{36}$ Second, Marxist thought that is free to grow and spread in Tunisia influence the younger generation to become followers of the leftist group. Third, their silting religious values by the government, both directly and intentionally or indirectly. Fourth, curbing the rights of political Islamic groups. Typically countries berasaskan secular actions it is inversely proportional to the secular understanding of itself. And fifth, the growing materialism and pragmatism in religion. The absence of political space to voice the aspirations of the Muslims and the massive secularization of the government led to the Tunisian people become apathetic to religion and state. They become less concerned about religion. Religious symbols utilized for imaging and profit as much as possible. Religious activities carried out merely on ceremonial moments, nothing more than that. Do not expect the values of the religious into the substance in people's behavior.

\section{The Relationship Between Religious Behavior in Text Ath-Thaliyâniy with Social Reality Society Tunisia}

Ath-Thaliyâniy novel begins from the story ChâjjiMachmud funeral procession. The beginning of the story as well as the culmination of the story of the novel. At the end of the funeral procession of the events that surprised everyone present, namely beating the main

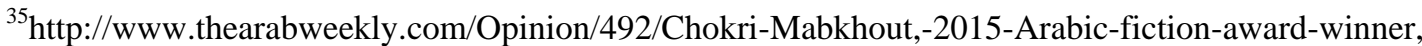
accessed 21 September 2016

${ }^{36}$ John L. Esposito, Rethinking Islam and Secularism, Guiding Papers Series the Assoociation of Religion Data Archives (ARDA), www.theARDA.com, p.2
} 
characterizations of the story, namely 'Abdun-Nasir, the' AllâlahDarwîsya priest at the funeral ceremony, which caused him almost fainting. The next story reveal any figures that played around the main characterizations with backward flow approach, which is all a story and his role until the end of the story to explain what exactly is the reason why 'AbdunNasir hit' the AllâlahDarwîsy.

The highlight of the funeral procession story can be interpreted as Yasmin revolution events that occurred in Tunisia. Crowds in procession, led by the Imam and all present concurred prayers said over him the illusion that the Tunisian people do not know what exactly had happened in his country. They had been subject and obedient course on any policy and the treatment of them. Until finally they realized that the leader had been beaten to fall to humiliation and surrender power. This story actually uncover the fall-'Abidin president Zainal Bin 'Ali from power who fled to Saudi Arabia. So, with Imam 'AllâlahDarwîsy is a representation of Bin Zainal-'Abidin' Ali.

Story of the relationship between 'AllâlahDarwîsy with Sheikh Syâdziliy which is the relationship between in-law and the law of this and also inherited the helm of religious (imams) in the village is a representation of the two state leaders Tunisia, who took office (succession) of the previous leader, from Chabîb president Bûrqaibah to-'AbidinZainal Bin 'Ali.

Actually connecting (homology) ShaykhSyâdziliy with ChabîbBûrqaibah not entirely right. Because the character of Sheikh Syâdziliy much different from ChabîbBûrqaibah. ShaikhSyâdziliy is a respected figure in the village, while ChabîbBûrqaibah though respected and regarded as the father of the nation of Tunisia by his people, he is considered to have disabilities history as the authoritarian president, Vile, and cruel to people, especially to the Islamic group. If so, what connects Sheikh Syâdziliy with ChabîbBûrqaibah as homologous correlation, while the two characterizations of the characters seem contradictory? To see the ugliness and ugliness BûrqaibahChabîb characters in this novel can be observed in temperament and behaviorJunainah, son of ShaikhSyâdziliy. Thus, the child and the father of two characters, Sheikh Syâdziliy and Junainah, assembled into one character ChabîbBûrqaibah. That is, it can be said that ChabîbBûrqaibah has multiple personalities. Have the good and the positive in the eyes of its people, but on the other hand he has a bad reputation for some communities in Tunisia others. Author in this case did not dare to come clean to express directly homology to the first president of Tunisia. This is 
understandable because the author himself Tunisian citizen who feels not expose the ugliness and ugliness beautiful own president.

How the characters and characterizations ShaykhSyâdziliyJunainah so both are a representation of ChabîbBûrqaibah. ShaikhSyâdziliy in addition as a religious figure, he is also a great artist (read: religious) in Tunisia. He was always invited by state officials, even the president himself Bûrqaibah also invited, to fill the official state occasions such as reading and prayers, hymns or readings Arabic poetry accompanied by musical instruments Arab art is complete. It may be said that ShaykhSyâdziliy inherited culture and distinctive art of Tunisia that not everyone has the skill.

Both brothers (Shalachud-Din and 'AbdunNasir) can be represented as two large families clumps Arab nations, namely Saudi Masyriq (East) and the Arab Maghrib (the West). Shalachud-Din is a representation of a clump of Arabs Masyriq, while 'AbdunNasir as part of the Arab Maghrib grove. Arab Masyriq can be said to be more prosperous than the Arab Maghrib. In general, Arab countries Masyriq identical with those countries that have natural resources such as oil and gas, especially the Gulf countries.

1) Religious Thought in Novel

The debate about Islamic thought also to be part of the novel's Ath-Thaliyâniy. Referring to the opinion of al-Ghanûsyiy mentioned above, there are three characterizations that represent the three religious groups. Third characterizations in question is adultery which represents the traditional Islamic thought, al-Qadir Billah Travolta who represent thought salafi (revivalists), and 'Abdun-Nasir himself as a representative of Islamic thought rational. The tone of the debate third characterizations of Islam on campus where they study. All three are activists of the student organization representing theirs and have the same mission as recruiters of students to get into the organization.

In the debate, criticize adultery all-out all thought of each group of the organization. Starting from the left considers the group's ideology and theoretical centralized. He considers those more inclined left discourse and too idealism in society. Even with hard Zina said the men left was none other than they are just blind dogs who only eat junk Lenin and Stalin alone.

While criticizing the group left, he also criticized the Islamist groups that are more likely to move only (group Ikhwan), but is not provided with adequate scientific reasoning. For him, Islam is not only to discuss the 'ubudiyah per se, but more than that Islam has developed a philosophical and historical kalam. A deep understanding of Islam because he 
likes to read books that invite to develop logical thinking. He's been reading Islamic books on various aspects, such as Islamic philosophy, theology, exegesis, Hadith and other Islamic disciplines. Deep insights about classical Islamic accompanied by criticism of the two conflicting groups, a group of Salafi and rational, can be included as a representation of traditional Islamic groups in Tunisia. The majority of Islamic thought that developed and accepted by the Tunisian society is traditionally thought of this.

2) Gender Equality in Novel

Within this novel, if observed explicitly actually no debate or discussion about gender. Indeed, there is an expression of gender concerns in the form of the reasons that lay ShaikhSyâdziliyJunainahschool because they think women do not need high school and critique poetry adultery against al-Qadir Billah Travolta is impressed degrading to women. In terms of the characterizations of course there are some women who dominate the story. Among these are HajjahZainab, Junainah, adultery, and Rîm. All of them are women who have a close relationship that the main characterizations, ie 'AbdunNasir. HajjahZainab as her mother 'AbdunNasir.Junainah person ever close to him when he was a teenager. Adultery as a close friend in college and later became his wife. Rîmis a close friend in the office after he was divorced with adultery. The women are contributing to the growth and development of the 'AbdunNasir from childhood to adult.

Description characterizations mother, HajjahZainab, cruel, harsh, and discipline to educate represented as "motherland" or the Tunisian nation itself. Then the cruel and harsh actions can be interpreted as favoritism nation against its own people. Her people prefer the bourgeoisie (capitalists) are rich compared to the poor. Her people are more concerned with imaging both at the international ketimpang think about the fate of his own people.

In the context of gender equality, Junainah, adultery, and Rîm is the representation of women victims of gender equality policy is misguided in Tunisia. The policy was made just to impress the world that Tunisia is the only country in the Middle East to implement gender equality and eliminate discrimination against women. The policy was made without considering the social and cultural background of Tunisia is more characterized by Islam. Reference Islam does not serve as the basis before deciding on the policy. In fact, the results of these policies even against the teachings of Islam.

The policies made by the government of which monopoly rights of women on himself, gives custody of children is greater for women in divorce and deleting clause law private rights (PSC), which states that women must obey their husbands. The government set up a fund to help women who need the cost of divorce and parenting of their children. 
However, the policies do not correspond with the reality on the ground. Precisely that happened instead of government repression and systematic violence against women, especially women of Islamists and Marxists. In fact, the woman or her family members allegedly have any affiliation with the banned political party were also arrested and imprisoned.

Junainah and Rîmis actually not victims of the repression of women's rights, but in fact they are the victims of their own freedom. Junainah indeed the victim of his father's narrow thinking about women.A critique of the Islamic community who still holds the principle of paternalistic and stereotypes against women. On the other hand, Sheikh Syâzdiliy not entitled to regulate the life Junainah free every night out of the house with her male friend, because Junainah are considered adults to govern themselves. Similarly, Rîm is free to do cohabiting, without no one has the right to call it. This he did and the state is entitled to protect their rights.

Another case with adultery, he did not know what to complain to anyone and he could only save her suffering when she was raped by her own father when he was little. Rape of a father to his own son he was supposed to protect a symbol of the cruelty of the regime is repressive to its own citizens, as experienced by Muslim women activists in Tunisia.

3) Social Media and gossip in the Novel

Gossip mothers officials about the origin of Ath-Thaliyâniy in a meeting and untrue stories about politics and gossip officials and artists published in newspapers and magazines in this novel, is a representation of gossip made through social media as it is today. Everything is equally talk about gossip, gossip, and some even lead to defamation. All want to know the latest information (up dated).

The development of information technology and communication technology benefits can make a world far everything had seemed to be close. Access to the world of science more easily. People no longer need to go far away to the library. Simply by opening the internet any kind of book you want is already available. In a religious context, via the internet a person can learn to teachers of religion (religious teacher) he wants. Can get information about the religious with ease.

The negative impact of the world information and communications technology is of course very much and dangerous. Not just mere gossip news and rumors, but also contain elements of pornography, prostitution transactions, gambling, and drug sales. In the 
context of religious concern when someone accesses the site that smelled radical invited to commit terror in the name of religion.

\section{G. Conclusion}

The novel tells the story of the characterizations ofAbdunNasirAth-Thaliyâniy and the people around him represents the change of religious behavior of the Tunisian nation. The process of secularization that is done massively have alienated people from religion. Judging from the content of the story, this novel has met the criteria ofSwingewood's sociology of literature, in theory, because in it there is a discussion of the social community using the data of literature.

Other criteria are also required by Swingewood, this novel can be summarized as a social mirror, because it gives a message to the Tunisian people for their return to the nation's identity as a Muslim Arab. In terms of production, it is one of the best-selling novel, let alone selected as the best Arabic literature in 2015. In relation to the history, the novel can be regarded as a social documentary on the history of social and political society Tunisia in the period between the 1960s until the year 1980s. The novel can be described from the psychological atmosphere of Tunisian society to face the authoritarian regime in power at the time.

There are at least five factors that lead to the changes of religious behaviorsof the Tunisian nation. First, secularization is systematically applied by the Tunisian government through policies that are oriented to the West, such as in the field of culture and education system. Second, Marxist thought that is free to grow and spread in Tunisia influence the younger generation to become followers of the leftist group. Third, their silting religious values by the government, both directly and intentionally or indirectly. Fourth, curbing the rights of political Islamic groupswher the Tunisian government restricts the right of political Islamic groups. Islamic groups are not free to move or to voice their political aspirations. They are suspected of political activities and many were sent to prison. And lastly, the growing of materialism and pragmatism in religion.

Changes in religious behavior Tunisian society which is disclosed in the novel can be divided into three groups. The first group of about changing behavior towards normative religious teachings, such as not running a religious duty, do not pray for his dead parents, lack of integrity of Islam (murû'ah), and a lack of insight into the religious knowledge. The second group of behavioral change in attitude of personality, such as drunkenness and sloppy lifestyle, gossiping and meddling in other people's affairs, lazy and talkative, 
lacking the authority and firmness, extravagance and wasteful, behavinghypocritely (hypocritical), and acts of lying, and slanderousness. Meanwhile,thethird group behavioral changes is related to family values, such as educating children with hard and rough approach; behaving against the parents; seclusion, committiing adultery and promiscuity; and sexual abuse of children. This is the conclusion of the research and it is hoped that it can be a learning experience.

\section{H. Bibliography}

Ancok, Djamaludin, Psikologi Islam, Yogyakarta: PustakaPelajar, 2011.

Butterworth, Charles E.,Between the State and Islam, Cambridge: Cambridge University Press, 2001.

DeLong-Bas, NatanaJ. 2012. "The New Social Media and the Arab Spring" http://www.oxfordislamicstudies.com/Public/focus/essay-

0611_social_media.html.,accessed 5February 2017.

Departemen Pendidikan dan Kebudayaan,Kamus Besar Bahasa Indonesia, Jakarta: Balai Pustaka, 1995.

Eco,Umberto,The Limits of Interpretation, Bloomington-Indianapolis: Indiana University Press, 1994.

Esposito,John L.,Rethinking Islam and Secularism, Guiding Papers Series the Assoociation of Religion Data Archives (ARDA), www.theARDA.com, accessed 27 September 2016

Ghannusyiyal-, Râsyid, Min Tajarrubât al-Harakat al-'Islâmiyyat fî Tûnis, Tûnis: Markaz al-Maghârib li al-Buhûtsi wa al-Tarjamah, 2014.

http://www.thearabweekly.com/Opinion/492/Chokri-Mabkhout,-2015-Arabic-fictionaward-winner

Lapidus,Ira M., History of Islamic Societies, Cambridge: Cambridge University Press, 2002.

Mabkhût al-, Syukrî, al-Thaliyâniy,Tûnis: Dâr al-Tanwîr li al-Thibâah wa al-Nasyr, 2014

Mahmoud,Abdesselem, "Social Movements in Tunisia and Egypt: A Tale of Two Revolutions" in International Journal of Social Science Studies, Vol. 3, No. 3; May 2015. 
Monica Marks, "Women's Rights before and after the Revolution" in The Making of the Tunisian Revolution: Contexts, Architects, Prospects, NouriGana (ed.), Edinburgh: Edinburgh University Press, 2013.

Nasution, Harun,Pembaharuandalam Islam, SejarahPemikirandanGerakan, Jakarta: BulanBintang, 1999.

Nasution, HarundanAzyumardiAzra (Ed.),Perkembangan Modern dalam Islam, Jakarta: YayasanObor Indonesia, 1985.

Perkins, Kenneth J., A History of Modern Tunisia,Cambridge: Cambridge University Press, 2004.

Rakhmat,Jalaluddin, Psikologi Agama, Bandung: PustakaMizan, 2003.

Swingewood, Alan,"Theory” in Diana Laurenson\& Alan Swingewood, The Sociology of Literature, London:Paladin, 1972. 